\title{
INDOMETHACIN, CAFFEINE AND PROCHLORPERAZINE ALONE AND COMBINED REVERT HYPERALGESIA IN IN VIVO MODELS OF MIGRAINE
}

\author{
NICOLETTA GALEOTTI ${ }^{\mathrm{a}}$, CARLA GHELARDINI ${ }^{\mathrm{a}}$, IRENE GRAZIOLI ${ }^{\mathrm{b}}$ and \\ CARLA USLENGHI ${ }^{\mathrm{b}, *}$ \\ ${ }^{a}$ Department of Preclinical and Clinical Pharmacology, University of Florence, Florence, \\ Italy, ${ }^{b}$ Medical Department, Solvay Pharma S.p.A., Grugliasco, Torino, Italy
}

Accepted 17 June 2002

\begin{abstract}
The combination of indomethacin, caffeine, and prochlorperazine (hereinafter IndoProCaf) represents an effective antimigraine drug available on the Italian market. The aim of this study was to test the efficacy of the three active principles alone and in combination in reverting hyperalgesia. Hyperalgesia was induced by morphine withdrawal in mice treated with morphine for 15 days and then made hyperalgic by morphine substitution with water. This study showed that indomethacin $0.3 \mathrm{mg} \mathrm{kg}^{-1}$, i.p.; caffeine 0.1 and $0.3 \mathrm{mg} \mathrm{kg}^{-1}$, i.p.; and prochlorperazine $0.1 \mathrm{mg} \mathrm{kg}^{-1}$, i.p.; as well as the combination of the three active principles, were able to revert morphine withdrawal induced hyperalgesia, causing a statistically significant increase of pain threshold in hyperalgic mice. In a second model, hyperalgesia was induced by the i.p. injection of a $0.3 \%$ solution of acetic acid in mice and was evaluated counting the number of abdominal constrictions. Indomethacin $\left(0.1 \mathrm{mg} \mathrm{kg}^{-1}\right.$, i.p.), caffeine $\left(0.3 \mathrm{mg} \mathrm{kg}^{-1}\right.$, i.p.), and prochlorperazine $\left(0.1 \mathrm{mg} \mathrm{kg}^{-1}\right.$, i.p.) reduced the number of abdominal constrictions, while the combination of the three active principles was able to abolish almost completely the abdominal constrictions, with a significantly higher efficacy compared to the single active principles. In both models, indomethacin, caffeine, and prochlorperazine reverted hyperalgesia at dosages 10 times lower than the corresponding analgesic ones. These data provide the pharmacologic evidence of the efficacy of IndoProCaf in reverting hyperalgesia, a condition of reduction of pain threshold similar to that occurring in migraine.
\end{abstract}

() 2002 Elsevier Science Ltd. All rights reserved.

KEY WORDS: indomethacin, caffeine, prochlorperazine, hyperalgesia, migraine.

\section{INTRODUCTION}

Migraine is a chronic condition characterized by episodic attacks of headache commonly associated with various combinations of nausea, vomiting, photophobia, and phonophobia. It is a common disorder with 1-year prevalence estimates of around 10-12\%, age- and genderdependent and 2-3 times more common in women than in men [1]. Several different theories on migraine etiopathology have been developed along the years and up to now none of the hypotheses are able to explain all the clinical and physiopathological aspects of migraine. Moreover, all the experimental models of migraine implemented until now are almost exclusively in vitro and the pharmacological screening of potential antimigraine drugs is prevalently carried out on vascular isolated preparations [2].

\footnotetext{
${ }^{*}$ Corresponding author. Medical Department, Solvay Pharma S.p.A., Via della Libertà 30, 10095 Grugliasco Torino, Italy.

E-mail: carla.uslenghi@solvay.com
}

Considering that in vivo models of migraine were not available, an experimental mouse model correspondent to migraine human pain was set up [3]. The model was based on the observation that morphine withdrawal syndrome is characterized by a hyperalgesia very similar to the reduction of pain threshold characteristic of migraineurs [4]. Previous experiments have shown that drugs used for the treatment of migraine as sumatriptan and ergotamine are effective in the model of hyperalgesia induced by morphine withdrawal with their antihyperalgic effect showing up at doses also 300 times lower for sumatriptan and 50 times lower for ergotamine compared to the correspondent analgesic ones $[3,5,6]$. The above-mentioned drugs resulted therefore active in this test of hyperalgesia at doses corresponding more to the ones used in clinical practice for the treatment of migraine.

Our personal experiences showed that the antihyperalgic activity of sumatriptan and ergotamine was confirmed also in another model of hyperalgesia induced through the intraperitoneal (i.p.) injection of a $0.3 \%$ solution of acetic 
acid. The correspondence of the active doses in the two experimental models and the evidence that potent analgesic drugs as morphine, which is not useful in the treatment of migraine, are not active in the $0.3 \%$ solution of acetic acid abdominal constriction test, also testify that this test is a valid in vivo migraine model.

The combination of indomethacin, caffeine, and prochlorperazine (Solvay Pharma S.p.A., Grugliasco, Torino, Italy) is an effective antimigraine drug available on the Italian market, where it is the most popular and used antimigraine treatment (IMS data). The aim of this study was to investigate if the three active principles alone and in combination were able to revert the morphine withdrawal induced hyperalgesia and the $0.3 \%$ solution of acetic acid induced hyperalgesia.

\section{MATERIALS AND METHODS}

\section{Animals}

Male albino mice (20-25 g) from Morini (San Polo d'Enza, Italy) were used. All experiments were carried out according to the guidelines of the European Community Council on animal care.

\section{Drugs}

The following drugs were used: indomethacin (nonsteroidal antiinflammatory drug NSAID—Sigma, Milano), caffeine (adenosine antagonist—Sigma, Milano), prochlorperazine $\left(\mathrm{D}_{2}\right.$-antagonist-Sigma, Milano), oxotremorine (muscarinic agonist-Fluka, Milano), amitriptyline (tricyclic antidepressant-Sigma, Milano), baclofen $\left(\mathrm{GABA}_{\mathrm{B}}\right.$ agonist—RBI, Milano), and diclofenac (NSAID—Sigma, Milano). The doses of all the drugs used in the two models of hyperalgesia were chosen on the basis of the evidence that such doses are not antinociceptive both in the hot plate test and in the $0.6 \%$ solution of acetic acid induced abdominal constriction test. In the latter test the nonantinociceptive doses resulted: $0.1 \mathrm{mg} \mathrm{kg}^{-1}$, i.p. for indomethacin; $0.3 \mathrm{mg} \mathrm{kg}^{-1}$, i.p., for caffeine; $0.1 \mathrm{mg} \mathrm{kg}^{-1}$, i.p., for prochlorperazine; $0.01 \mathrm{mg} \mathrm{kg}^{-1}$, i.p., for oxotremorine; $0.5 \mathrm{mg} \mathrm{kg}^{-1}$, i.p., for amitryptiline; $0.2 \mathrm{mg} \mathrm{kg}^{-1}$, i.p., for baclofen; and $1 \mathrm{mg} \mathrm{kg}^{-1}$, i.p., for diclofenac; while indomethacin $1 \mathrm{mg} \mathrm{kg}^{-1}$, i.p.; caffeine $3 \mathrm{mg} \mathrm{kg}^{-1}$, i.p.; prochlorperazine $1 \mathrm{mg} \mathrm{kg}^{-1}$, i.p.; oxotremorine $0.04 \mathrm{mg} \mathrm{kg}^{-1}$, i.p.; amitryptiline $5 \mathrm{mg} \mathrm{kg}^{-1}$, i.p.; baclofen $2 \mathrm{mg} \mathrm{kg}^{-1}$, i.p.; and diclofenac $10 \mathrm{mg} \mathrm{kg}^{-1}$, i.p., were all effective.

\section{Morphine administration schedule}

Mice were randomly assigned to either the morphinetreated group or one of two control (tap water or 5\% saccharose) groups. Morphine-treated mice received a solution of morphine, dissolved in 5\% saccharose solution, in their water bottles in increasing doses as follows: days 1 and $2,0.1 \mathrm{mg} \mathrm{ml}^{-1}$; days 3 and $4,0.2 \mathrm{mg} \mathrm{ml}^{-1}$; days 5 and $6,0.3 \mathrm{mg} \mathrm{ml}^{-1}$; days $7-15,0.4 \mathrm{mg} \mathrm{ml}^{-1}$. On day 15 , the morphine and saccharose solutions were replaced with tap water at a time referred to as $0 \mathrm{~h}$. Four hours after the replacement with water, mice showed a significant reduction of pain threshold in the hot plate test that reached the highest intensity after $6 \mathrm{~h}(11.8 \pm 0.8 \mathrm{~s}$ of licking latency $v \mathrm{~s}$ $15.7 \pm 1.1 \mathrm{~s}$ in the control group). All the drugs under investigation were administered i.p. in correspondence with their analgesic peak according to their pharmacokinetic characteristics and in particular prochlorperazine $45 \mathrm{~min}$, indomethacin $30 \mathrm{~min}$ and caffeine $15 \mathrm{~min}$ before the sixth hour following the morphine removal. A control group was treated with a saline solution.

\section{Hot plate test}

The method adopted was described by O'Callaghan and Holtzman [7]. Mice were placed inside a stainless steel container, thermostatically set at $52.5 \pm 0.1^{\circ} \mathrm{C}$ in a precision water-bath from KW Mechanical Workshop, Siena, Italy. Reaction times (seconds) were measured with a stop-watch before (pretest) and after treatment. The endpoint used was the licking of the fore or hind paws. Those mice scoring below 12 and over $18 \mathrm{~s}$ in the pretest were rejected $(30 \%)$. An arbitrary cut-off time of $45 \mathrm{~s}$ was adopted. The licking latency values were recorded at regular intervals $(15 \mathrm{~min})$ starting from $6 \mathrm{~h}$ after morphine removal until further $30 \mathrm{~min}$ and the effect of the drugs under investigation was compared versus the saline-treated mice.

\section{Abdominal constriction test}

Mice were injected i.p. with a $0.3 \%$ solution of acetic acid $\left(10 \mathrm{ml} \mathrm{kg}^{-1}\right)$, that is half the percentage described by Koster et al. [8]. Caffeine was administered $10 \mathrm{~min}$ before the acetic acid injection, whereas indomethacin, oxotremorine, amitriptyline, baclofen, and diclofenac were administered $25 \mathrm{~min}$ and prochlorperazine $40 \mathrm{~min}$ before the acetic acid injection. The combination of indomethacin, caffeine, and prochlorperazine was administered $15 \mathrm{~min}$ before the injection of the $0.3 \%$ solution of acetic acid. The number of stretching movements was counted for $10 \mathrm{~min}$, starting $5 \mathrm{~min}$ after acetic acid injection.

\section{Statistics}

Results are given as the mean \pm SEM; the analysis of variance (ANOVA) was used to verify the significance between two means, followed by Fisher's PLSD procedure for post hoc comparison. $P$ values of less than 0.05 were considered significant. Data were analyzed with the StatView for the Macintosh computer program (1992).

\section{RESULTS}

\section{Hyperalgesia induced by morphine withdrawal}

Indomethacin $0.3 \mathrm{mg} \mathrm{kg}^{-1}$, i.p., was able to induce a statistically significant increase of pain threshold in mouse hot plate test in hyperalgic mice after $6 \mathrm{~h}$ from morphine removal in comparison with the control group (Fig. 1). 


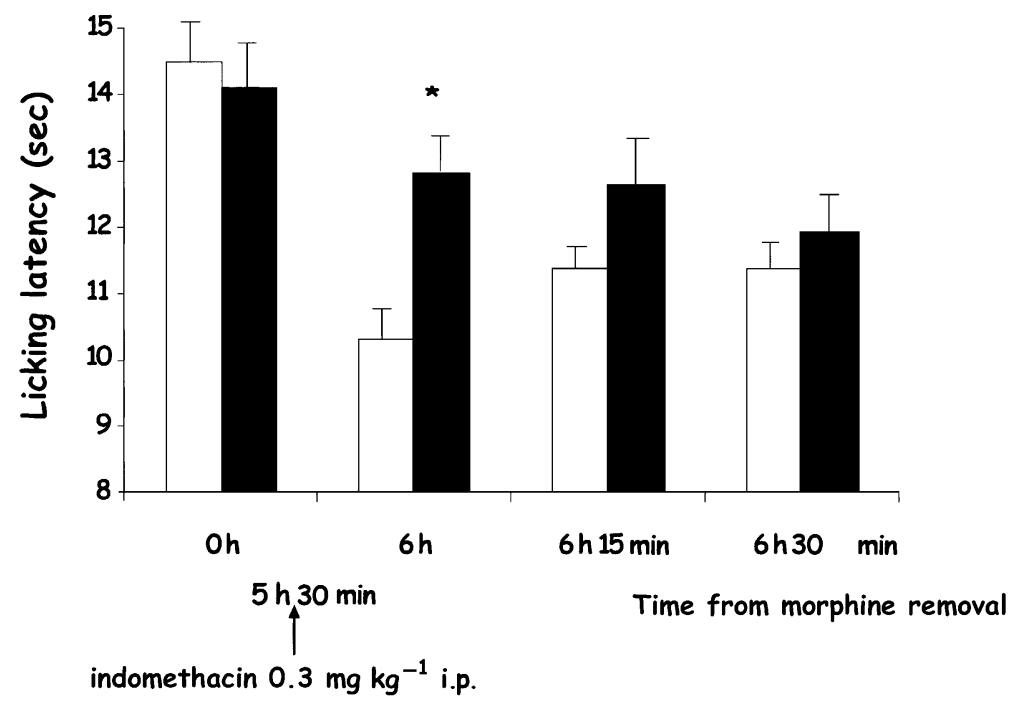

Fig. 1. Effect of indomethacin $\left(0.3 \mathrm{mg} \mathrm{kg}^{-1}\right.$, i.p.) on hyperalgesia induced by morphine withdrawal in mouse hot plate test. Each column represents the mean of at least 10 mice. All data are mean \pm SEM; $(*) P<0.05$ versus the corresponding nontreated mice (saline). ( $\square$ ) Saline and $(\square)$ indomethacin.

Caffeine at $0.3 \mathrm{mg} \mathrm{kg}^{-1}$, i.p., was able to revert morphine withdrawal-induced hyperalgesia, with a statistically significant increase of pain threshold at $6 \mathrm{~h}$ and $6 \mathrm{~h} 15 \mathrm{~min}$ after morphine removal (Fig. 2). Caffeine also at the dose of $0.1 \mathrm{mg} \mathrm{kg}^{-1}$, i.p., was active in this experimental model (data not shown). Prochlorperazine $0.1 \mathrm{mg} \mathrm{kg}^{-1}$, i.p., induced a statistically significant increase of pain threshold at all the observation times (Fig. 3). Also the combination of indomethacin $0.3 \mathrm{mg} \mathrm{kg}^{-1}$, caffeine $0.1 \mathrm{mg} \mathrm{kg}^{-1}$, and prochlorperazine $0.03 \mathrm{mg} \mathrm{kg}^{-1}$, i.p., resulted in being able to revert morphine withdrawal-induced hyperalgesia (Fig. 4). The combination of indomethacin $1 \mathrm{mg} \mathrm{kg}^{-1}$, caffeine $0.3 \mathrm{mg} \mathrm{kg}^{-1}$, and prochlorperazine $0.1 \mathrm{mg} \mathrm{kg}^{-1}$, i.p., that means three times a higher dosage of the three active principles, was able to induce a more prolonged antihyperalgic effect (data not shown).

Amitriptyline $0.5 \mathrm{mg} \mathrm{kg}^{-1}$, baclofen $0.2 \mathrm{mg} \mathrm{kg}^{-1}$, and diclofenac $1 \mathrm{mg} \mathrm{kg}^{-1}$, i.p., which are analgesic drugs not active in the resolution of migraine attack and tested as negative reference drugs, were not able to revert morphine withdrawal-induced hyperalgesia, while oxotremorine, another negative reference drug, resulted able to revert this type of hyperalgesia at the dose of $0.01 \mathrm{mg} \mathrm{kg}^{-1}$. The same doses of indomethacin, caffeine, and prochlorperazine able to revert morphine withdrawal-induced hyperalgesia were not able to increase the pain threshold in mice not treated with morphine, showing that the result was not due to an analgesic effect (Figs. 1-3).

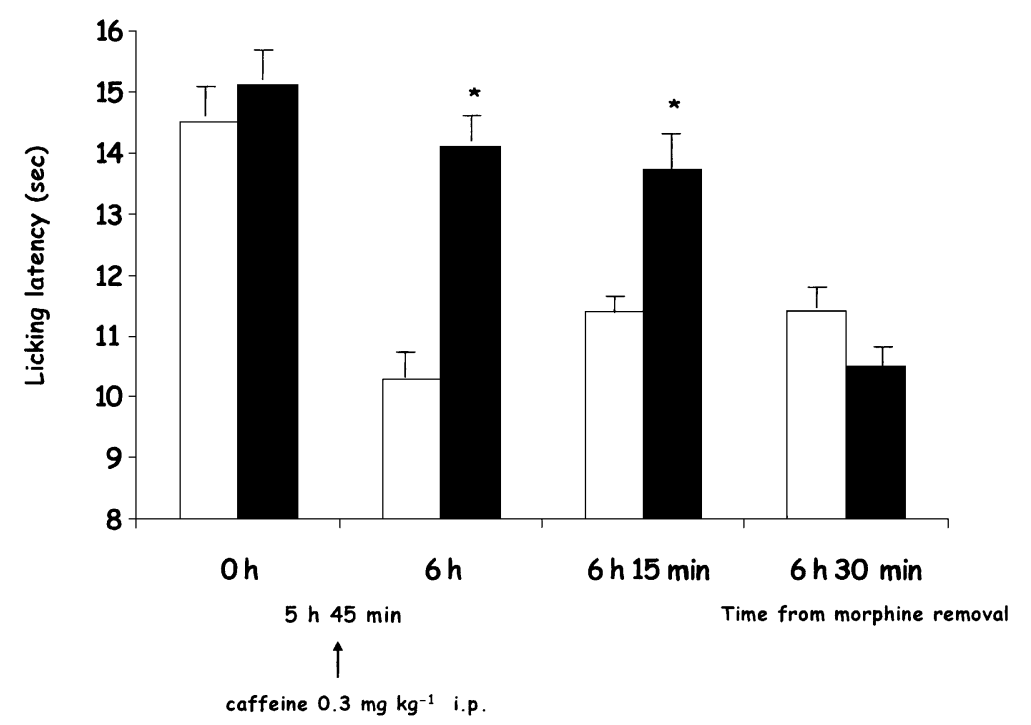

Fig. 2. Effect of caffeine $\left(0.3 \mathrm{mg} \mathrm{kg}^{-1}\right.$, i.p.) on hyperalgesia induced by morphine withdrawal in mouse hot plate test. Each column represents the mean of at least 10 mice. All data are mean \pm SEM; $(*) P<0.01$ versus the corresponding nontreated mice (saline). ( $\square$ ) Saline and $(\square)$ caffeine. 


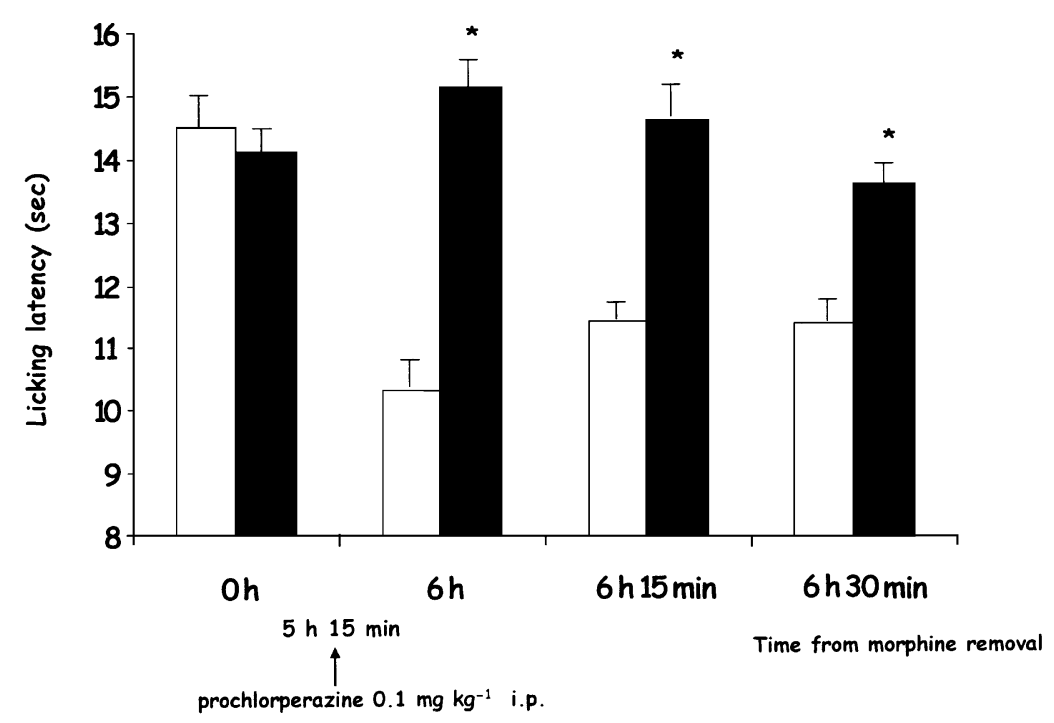

Fig. 3. Effect of prochlorperazine $\left(0.1 \mathrm{mg} \mathrm{kg}^{-1}\right.$, i.p. $)$ on hyperalgesia induced by morphine withdrawal in mouse hot plate test. Each column represents the mean of at least 10 mice. All data are mean \pm SEM; $(*) P<0.01$ versus the corresponding nontreated mice (saline). ( $\square$ ) Saline and ( $\square$ ) prochlorperazine.

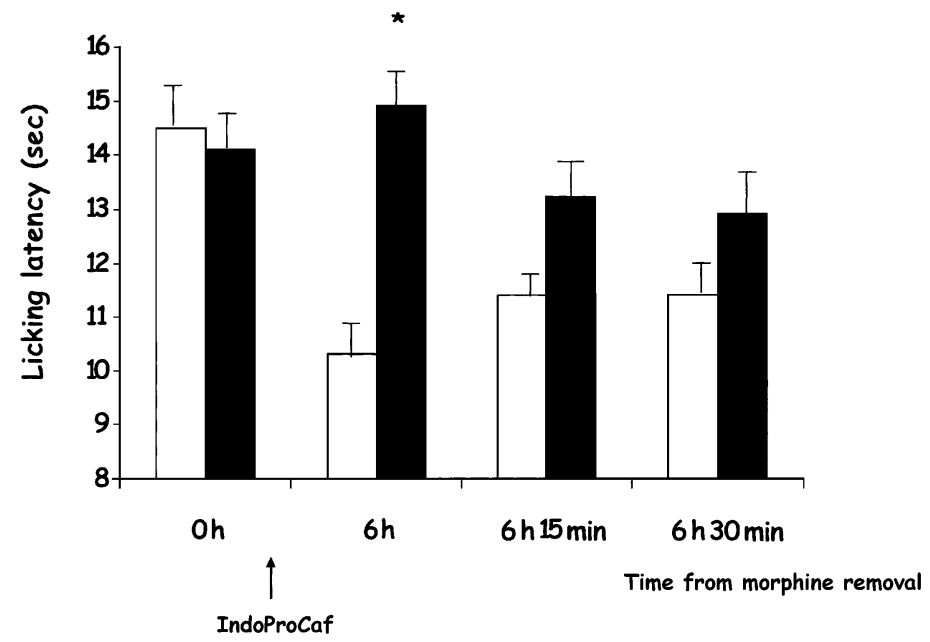

Fig. 4. Effect of IndoProCaf (indomethacin $0.3 \mathrm{mg} \mathrm{kg}^{-1}$, caffeine $0.1 \mathrm{mg} \mathrm{kg}^{-1}$, and prochlorperazine $0.03 \mathrm{mg} \mathrm{kg}^{-1}$, i.p.) on hyperalgesia induced by morphine withdrawal in mouse hot plate test. Each column represents the mean of at least 10 mice. All data are mean \pm SEM; $(*) P<0.01$ versus the corresponding nontreated mice (saline). ( $\square$ ) Saline and (ם) IndoProCaf.

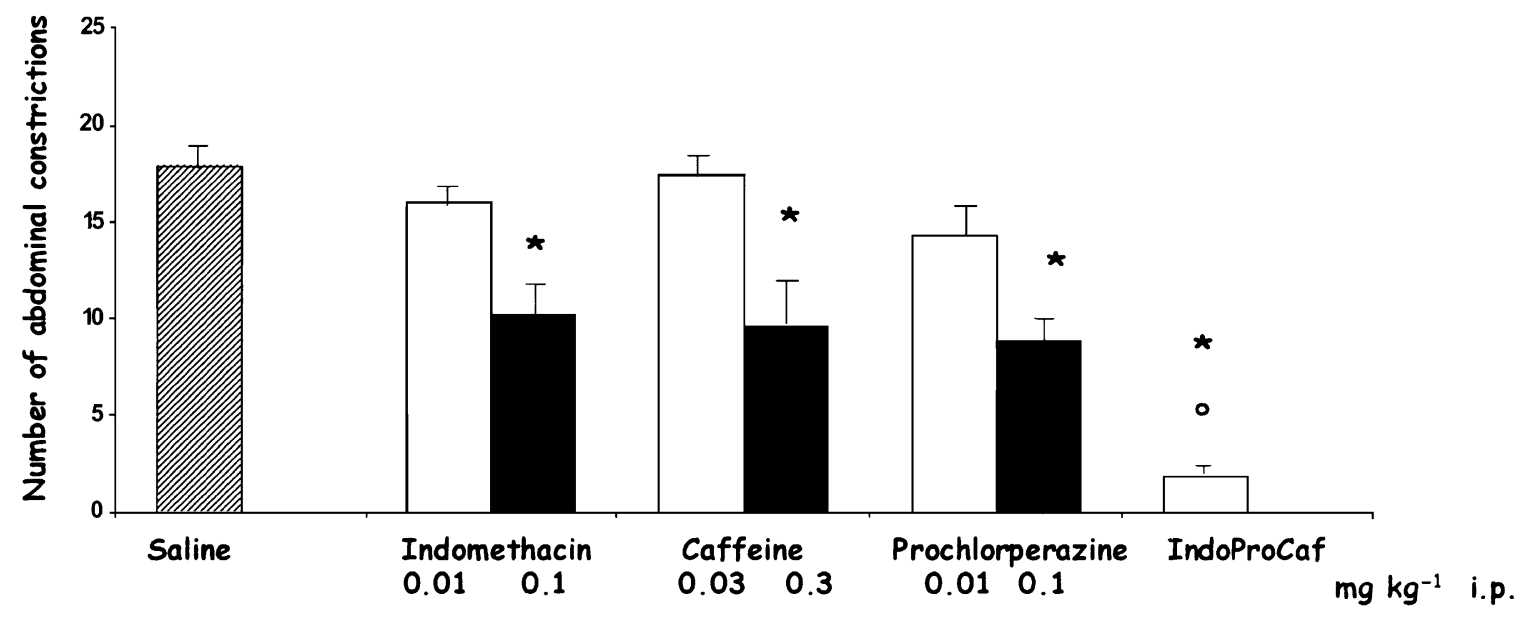

Fig. 5. Effect of IndoProCaf (indomethacin $0.1 \mathrm{mg} \mathrm{kg}^{-1}$, caffeine $0.3 \mathrm{mg} \mathrm{kg}^{-1}$, prochlorperazine $0.1 \mathrm{mg} \mathrm{kg}^{-1}$, i.p.) in mouse abdominal constriction test induced by a $0.3 \%$ solution of acetic acid. Each value represents the mean of two experiments. All data are mean \pm SEM; $(*) P<0.05$ versus saline controls and $\left({ }^{\circ}\right) P<0.01$ versus indomethacin or caffeine or prochlorperazine-treated mice. 


\section{Hyperalgesia induced by a $0.3 \%$ solution of acetic acid}

In this model the effect of the following drugs was tested: indomethacin 0.01 and $0.1 \mathrm{mg} \mathrm{kg}^{-1}$, i.p.; caffeine 0.03 and $0.3 \mathrm{mg} \mathrm{kg}^{-1}$, i.p.; prochlorperazine 0.01 and $0.1 \mathrm{mg} \mathrm{kg}^{-1}$, i.p.; oxotremorine 0.001 and $0.01 \mathrm{mg} \mathrm{kg}^{-1}$, i.p.; amitriptyline 0.5 e $5 \mathrm{mg} \mathrm{kg}^{-1}$, i.p.; baclofen 0.2 and $2 \mathrm{mg} \mathrm{kg}^{-1}$, i.p.; and diclofenac 0.1 and $1 \mathrm{mg} \mathrm{kg}^{-1}$, i.p. Indomethacin $0.1 \mathrm{mg} \mathrm{kg}^{-1}$, caffeine $0.3 \mathrm{mg} \mathrm{kg}^{-1}$, prochlorperazine $0.1 \mathrm{mg} \mathrm{kg}^{-1}$, and diclofenac 1 and $0.1 \mathrm{mg} \mathrm{kg}^{-1}$ reduced the number of abdominal constrictions, while amitriptyline and baclofen were able to reduce the number of abdominal constrictions only at the analgesic dosage and oxotremorine resulted active at $0.01 \mathrm{mg} \mathrm{kg}^{-1}$.

The combination of indomethacin $0.1 \mathrm{mg} \mathrm{kg}^{-1}$, caffeine $0.3 \mathrm{mg} \mathrm{kg}^{-1}$, and prochlorperazine $0.1 \mathrm{mg} \mathrm{kg}^{-1}$ resulted able to abolish almost completely the abdominal constrictions, with a statistically significant difference in comparison with each active principle (Fig. 5).

\section{DISCUSSION}

The aim of this study was to evaluate if indomethacin, caffeine, and prochlorperazine alone and combined were able to revert hyperalgesia in in vivo models of migraine.

This study showed that indomethacin, caffeine, and prochlorperazine are all active in reverting hyperalgesia induced both by morphine withdrawal and by a $0.3 \%$ solution of acetic acid at doses at least 10 times lower than the corresponding analgesic ones. It is known that indomethacin is analgesic at the dose of $10 \mathrm{mg} \mathrm{kg}^{-1}$, i.p., in the formalin test in mice [9]. According to our experience, indomethacin is analgesic also at the dose of $1 \mathrm{mg} \mathrm{kg}^{-1}$, i.p., in the $0.6 \%$ solution of acetic acid test in mice, while it resulted in reverting hyperalgesia at the dose of $0.1 \mathrm{mg} \mathrm{kg}^{-1}$, i.p., in the $0.3 \%$ solution of acetic acid test and at the dose of $0.3 \mathrm{mg} \mathrm{kg}^{-1}$, i.p., in the morphine withdrawal test. Caffeine produced significant analgesia both in mice at the doses of $1-5 \mathrm{mg} \mathrm{kg}^{-1}$, s.c. and in rats at the doses of $2.5-5 \mathrm{mg} \mathrm{kg}^{-1}$, i.p. [10], while its antihyperalgic effect was evident up to $0.1 \mathrm{mg} \mathrm{kg}^{-1}$, i.p. Prochlorperazine resulted analgesic at the doses of 1 and $2 \mathrm{mg} \mathrm{kg}^{-1}$, i.p., in mice [11], while it resulted in reverting hyperalgesia at the dose of $0.1 \mathrm{mg} \mathrm{kg}^{-1}$, i.p. Furthermore, the antihyperalgic effect of the three active principles is not dependent on the analgesic activity of the three drugs, considering that the same doses of indomethacin, caffeine, and prochlorperazine in reverting morphine withdrawal induced hyperalgesia are not able to increase the pain threshold in mice not treated with morphine.

The results of this study also showed that the combination of indomethacin, caffeine, and prochlorperazine not only induced a statistically significant increase of pain threshold in the morphine withdrawal test, but was also able to abolish almost completely the abdominal constrictions, with a significantly higher efficacy compared to the single active principles. It represents a synergic effect of the combination. It is also important to note that the dose-ratio used for the combination in the experimental models (ratio: indomethacin 1 , caffeine 0.3 , and prochlorperazine 0.1 ) corresponds to the dose-ratio of the therapeutic dose used in both the oral and rectal forms of IndoProCaf, the only different ratio being caffeine (in the experimental models a dose-ratio 10 times lower was used). The dose range of indomethacin contained in IndoProCaf is $25-50 \mathrm{mg}$, a lower dose compared to the antirheumatic dosage; the range of caffeine is $75-150 \mathrm{mg}$, while the dose range of prochlorperazine is $2-8 \mathrm{mg}$, a lower dose compared to the antipsychotic dosage.

Drugs as amitriptyline, baclofen, and diclofenac were not able to revert morphine withdrawal induced hyperalgesia.

Notwithstanding the availability of the triptans since the beginning of the 1990s, the combination of indomethacin, caffeine, and prochlorperazine still represents nowadays the most popular and used antimigraine treatment in the Italian market. All the active principles are very well-known drugs, available world-wide on the market, used in different indications, indomethacin as a NSAID, caffeine in different analgesic preparations, prochlorperazine at high doses as an antipsychotic [12] and at low doses as an antiemetic drug [13]. However, each active ingredient has specific antimigraine properties. Indomethacin showed a central analgesic activity which has not been demonstrated for other NSAIDs and a central vasoconstrictive activity [4, 14]. Moreover, indomethacin is the only NSAID with a structural formula very similar to serotonin and to the triptans. Caffeine, used as an analgesic adjuvant [15-17], is endowed with its own central analgesic cholinergic and vasoconstrictive activity $[10,18]$. Prochlorperazine is effective against vomiting, typical of migraine attacks and also has its own antimigraine efficacy proved in a clinical trial versus metoclopramide [13]; its analgesic effect, mediated through a central amplification of cholinergic transmission, was proven in the mouse hot plate test and in the abdominal constriction test [11]. The efficacy of the three active principles alone, and in combination in the two models of hyperalgesia, may help to explain the clinical efficacy of IndoProCaf in the treatment of migraine, a pathological condition characterized by an excessive sensitivity to pain.

\section{REFERENCES}

1. Breslau N, Rasmussen BK. The impact of migraine: epidemiology, risk factors, and co-morbidities. Neurology 2001; 56(6 Suppl 1): 4-12.

2. De Vries P, Villalon CM, Saxena PR. Pharmacological aspects of experimental headache models in relation to acute antimigraine therapy. Eur J Pharmacol 1999; 375(1-3): 61-74.

3. Ghelardini C, Galeotti N, Donaldson S, Bartolini A. The antimigraine drug ergotamine is endowed with antihyperalgesic activity. Phytother Res 1998; 12: S10-2. 
4. Sicuteri F, Nicolodi M. La tesi olistica dell'emicrania. Ann Ital Med Int 1997; 12 (Suppl 1).

5. Ghelardini C, Galeotti N, Donaldson S, Nicolodi M, Sicuteri F, Bartolini A. Prevention by sumatriptan of hyperalgesia induced by morphine withdrawal. Fundam Clin Pharmacol 1996; 10: 192.

6. Ghelardini C, Galeotti N, Figini M, Imperato A, Nicolodi M, Sicuteri F, Gessa GL, Bartolini A. The central cholinergic system has a role in the antinociception induced in rodents and guinea pigs by the antimigraine drug sumatriptan. J Pharmacol Exp Ther 1996; 279: 884-90.

7. O'Callaghan JP, Holtzman SG. Quantification of the analgesic activity of narcotic antagonists by a modified hot-plate procedure. $J$ Pharmacol Exp Ther 1975; 192: 497-505.

8. Koster R, Anderson M, De Beer EJ. Acetic acid for analgesic screening. Fed Proc 1959; 18: 412-3.

9. Hunskaar S, Betge OG, Hole K. Dissociation between antinociceptive and anti-inflammatory effects of acetylsalicylic acid and indomethacin in the formalin test. Pain 1986; 25: 125-32.

10. Ghelardini C, Galeotti N, Bartolini A. Caffeine induces central cholinergic analgesia. Naunyn Schmiedebergs Arch Pharmacol 1997; 356: 590-5.

11. Ghelardini C, Galeotti N, Di Cesare Mannelli L, Uslenghi C, Grazioli I, Bartolini A. Investigation into the analgesic effect of prochlorperazine. 30th Annual Meeting Society for Neuroscience. New Orleans, Nov 2000: 2155

12. Servis M, Miller B. Treatment of psychosis with prochlorperazine in the ICU setting. Psychosomatics 1997; 38(6): 589-90.

13. Coppola M, Yealy DM, Leibold RA. Randomized, placebo-controlled evaluation of prochlorperazine versus metoclopramide for emergency department treatment of migraine headache. Ann Emerg Med 1995; 26(5): 541-6.

14. Hu X, Tang H, Li Q, Huang X. Central mechanism of indomethacin analgesia. Eur J Pharmacol 1994; 263: 53-7.

15. Sawynock J, Yaksh T. Caffeine as an analgesic adjuvant: a review of pharmacology and mechanisms of action. Pharmacol Rev 1993; 45(1): 43-85.

16. Castaneda-Hernandez G, Castillo-Mendez MS, Lopez-Munoz FJ, Granados-Soto V, Flores-Murrieta FJ. Potentiation by caffeine of the analgesic effect of aspirin in the pain-induced functional impairment model in the rat. Can J Physiol Pharmacol 1994; 72: 1127-31.

17. Granados-Soto V, Castaneda-Hernandez G. A review of the pharmacokinetic and pharmacodynamic factors in the potentiation of the antinociceptive effect of nonsteroidal anti-inflammatory drugs by caffeine. J Pharmacol Toxicol Methods 1999; 42(2): 67-72.

18. Ward N, Whitney C, Avery D, Dunner D. The analgesic effects of caffeine in headache. Pain 1991; 44: 151-5. 